\title{
Superficial View on Relationship between Curriculum Teaching and Practice Teaching in China
}

\author{
Ning Chen \\ College of Computer Science, Xi'an Polytechnic University, 710048, Xi'an, China \\ chennvictor@gmail.com
}

Keywords: Practical teaching; Curriculum teaching; Undergraduate education; Innovation ability ; Complementary teaching

\begin{abstract}
Objective: Undergraduate education should adhere to the basic value orientation.Methods: This paper interprets relation between curriculum teaching and practical teaching from three aspects of theory, practice and education objective.Results: Practical teaching is essential; it decides the direction and the depth of the curriculum teaching. Also curriculum teaching plays an important role in the undergraduate education.Conclusion: On the basis of the preliminary opinions, advocating of complementary curriculum teaching and practice teaching is concluded.
\end{abstract}

\section{Introduction}

In recent years, employment problem of undergraduate students in China has become increasingly prominent because of increasing employment pressure, so the employment of college students has become a social issue of concern. And for the employment of college students is one important reason, many employers reflects when the current graduates go to work, independent thinking and operation ability standing on one's own are poor, and the ability of independent innovation in the work must be increased, therefore many people will cause such consequences, that is, suspicion is aimed directly at the modern higher education system itself. For the higher education, reform was raised, a suggestion whether undergraduate education should focus on practical teaching and should weaken the curriculum teaching. We have the following several superficial views on this point of view $[1,2]$.

\section{Curriculum teaching plays an important role in the undergraduate education}

We think that the effect of curriculum teaching in undergraduate training should not be absolutely ignored and absolutely cannot be ignored. If we want to understand an important role of curriculum teaching in the cultivation of the undergraduate, we first need to understand what is 'branch curriculum', which is also called the 'subject curriculum'. It is science and cultural heritage, which is defined as the sum of course organized according to the most traditional foundation form of each subject. From the teaching content, teaching each course in classroom is based on the requirements of the syllabus focusing on theory, is teaching related professional basic theory content from different angles, and carries out the relevant professional scientific aspects of the education of undergraduate students. From the way of teaching, undergraduate students need to pass the correct and system inculcation of theory so as to have a good command of long-term accumulation of related professional theoretical knowledge in limited time. The curriculum teaching in teacher 
responsible manner is very important and is not replaceable manner. So, the curriculum teaching is main way for the undergraduate to obtain professional theory knowledge, the main way to have the basic ability, and the main way to complete the training objectives of undergraduate teaching.

Then, what is relation between students' access to professional theory knowledge and students with corresponding practical innovation ability? In fact, the theoretical knowledge and practical ability has a close relationship. Practice ability is the specific embodiment of the flexibility in the use of professional theory knowledge. Whether students with ability of practice and innovation is whether the students really master the relevant theoretical knowledge of the specialty; that is to say, if only undergraduate students have learned the theory of professional knowledge, but cannot flexible use without the development of innovative practice ability, then, they don't really have the corresponding professional theory and master the professional knowledge, but students do not has the ability of practice and innovation. To learn professional theoretical knowledge is not essential and can be replaced by practice, if you have such thoughts that is a mistake and the wrong.

How to make the future strength of our country - the contemporary undergraduate students - with an endless supply of innovation power and excellent innovation ability? Undergraduate students enter colleges and universities for undergraduate study, then, his starting point is certainly higher than other professional education or skills education students, of course, the target requirement for them to learn also certainly should be higher than other students. Because of the high starting point, undergraduate students are more open vision, knowledge information acceptance of larger, more efficient. It is well known, innovation is that people apply existing knowledge to creatively solve a problem. That is, the existing knowledge is the foundation of innovation. Only with a solid theoretical foundation, wide knowledge, it is possible for us to have better innovation ability. Without a solid theoretical foundation, but only with the concrete practice operation ability, then the innovative ideas will be bound and considering the problem will be restricted, thus knowledge advantage of undergraduate education on the skills and vocational education would be lost, and capability of creative solutions to problems would be lost. Therefore, we should establish such a concept, through the guidance and teaching in the completion of the course, and we have the professional theory knowledge and a solid theoretical foundation, we will be possible to have necessary to practice innovation [3].

\section{Some existing problems of curriculum teaching}

Because the curriculum teaching has an important role in the cultivation of undergraduate students, we should pay attention to the problems in the curriculum teaching process.

In the curriculum teaching process, teachers' teaching method although is mainly, but not to say that, in the teaching process of the course, it is cramming method of teaching, but it should be how to cultivate students' autonomous learning ability in the course teaching process, independent practice operation ability through the teaching has always been the goal of teaching. Long since, our country higher school have to stick to the traditional style of teaching and learning, and teachers to teach students simple, students to learn and learn, in such a way of teaching, students are nurtured to become talents with inheritance, model. The real aim is make students understand the learning, is not only knowledge, but knowledge should be in use. In order to solve this problem, the university teachers in the actual classroom teaching process for the traditional teaching mode has also made some reform, attempts to use the properly form, make the teaching content more rich, the students to understand the theory more clearly. Enable the students to understand and master these theoretical knowledge; teachers in the classroom teaching, it is necessary to combine the realistic 
problems, the hot, difficult problems in different periods of widespread concern, the theory and practice with the curriculum teaching activities.

In the teaching of the course, we should avoid general teaching and no key point, for example, with the rapid development of our country modernization, requirements for the modernization of information continues to improve, computer is basic courses as science and engineering, agriculture and medicine and other professional courses, but the computer teacher in many higher school, in the process of implementing different professional teaching, neglect different classes for different demand and emphasis, does not distinguish between professional computer and non computer majors, just a teaching scheme is simple to carry on teaching, as will cause the non computer professional students complain that the computer basic course is difficult and useless; if the computer professor in the course is fully considering the different profession, different categories of basic computer courses focus request, according to the basic computer courses for non computer majors emphasis on computer application in teaching, and less traditional computer technology foundation, and according to the basic course of computer professional computer neither ignore application, and should emphasize the professional and technical, so computer professional and non professional science calculation students will each takes what he needs, with real gains in teaching computer courses[4].

\section{Advocating of complementary curriculum teaching and practice teaching}

The modern higher education's teaching goal is to train undergraduates become talents of professional theory knowledge not only has the high level and practical operation ability and innovation ability. So, how to establish the new education adapt to the modern higher education training goal mode? We need to establish a curriculum teaching and practice teaching together with the new education complementary training mode [5].

We already know curriculum teaching is an important aspect of undergraduate teaching, and the first task is to build the course teaching of the professional curriculum system. Determine the professional curriculum system is reflected in a professional training blueprint, reflect a professional training objectives, and curriculum is an important component in training scheme, the undergraduates should have the basic theory and professional knowledge and skills of learning specific requirements. However, we should know that in the course of teaching course system should never be closed, in order to better meet the needs of society and the undergraduate curriculum system for training practice and innovation ability should be open, closely linked with the social pulse. The curriculum should embody systematic, innovative, courses should be combined with social practice, based on close contact with society, combined with the current social enterprises are facing a problem needed to be solved were selected, select the most close to the society and the progress of the times, the latest technological convergence of curriculum system, learning to help solve the problems of modern society. At the same time, they should also pay attention to combining the practice to deepen the study and understanding of professional theory in practice, that is to say, to understand and research learning, professional theory, can never be divorced from social practice[6,7].

Practice teaching is also an important aspect of training in the undergraduate teaching, a good implementation of practice teaching, to cultivate the practice ability of the undergraduates plays a very important role. How to carry out the practice teaching of undergraduates? In the practice teaching process, the teacher through continuous exploration, summarized in the practice of a lot of good teaching methods and ways -- test, actual operation, practice case and so on; of course, here the so-called test, the actual operation, practice case and so on and various methods of teaching 
method is to should fully consider the undergraduate education and other occupation education and skills education difference characteristics of undergraduate education, practice teaching cultivation objective cannot be the same with the occupation education and skills education -- only emphasizes the cultivation of focusing on specific operation skills, but should be professional theoretical knowledge into operation training to go to practice, and the church in the practice teaching process students' thinking in practice, learning in practice in summary, in practice, ability in the practice of refining $[8,9,10]$.

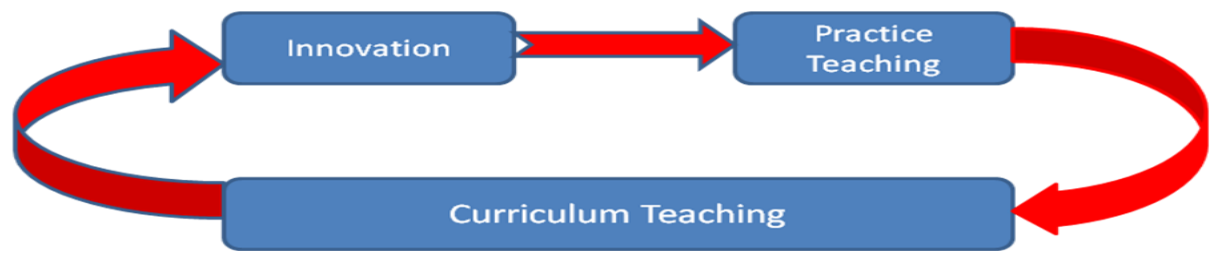

Fig.1 Complementary curriculum teaching and practice teaching

\section{Conclusion}

With the deepening of the development and Reform in the social economy and culture, the development of practical ability of students has been paid attention to by people, the source of knowledge is practice, and practice is the foundation of innovation. We think we should completely change the traditional education mode of practice teaching is in the subordinate status. Practice teaching and theory teaching should be parallel and coordinated, complementary shown in Fig.1. The construction of an important task of modern education and training mode of scientific and reasonable is must construct a reasonable teaching system for the students, that is, from the overall planning of each link of teaching, so that students in the teaching process should not only learn professional theoretical knowledge, but also can make practical learning under the guidance of the teacher. It can not only cultivate students' basic skills solid and the ability of practice, but also of great benefit to improve the comprehensive quality of students.

\section{Acknowledgment}

This work is supported by Quality Project of Academic Degree and Graduate Education of Xi'an Polytechnic University (13YZL05).

\section{References}

[1] Tunde Szecsi. Teaching Strategies: Creative Drama in Preschool Curriculum: Teaching Strategies Implemented in Hungary. Childhood Education, 2009, Vol.85 (2), pp.120-124.

[2] Clare Fleming. Creative curriculum: Teaching self-awareness in a day care system. Day Care and Early Education, 1982, Vol.9 (4), pp.7-11.

[3] Diansheng Chen, Zhen Li, Tianmiao Wang. Exploration and practice: A competition based project practice teaching mode. Mechatronics, 2013..

[4] Watmough Simon, O'Sullivan Helen, Taylor David. Graduates from a traditional medical curriculum evaluate the effectiveness of their medical curriculum through interviews. BMC Medical Education, 2009, 9(1). 
[5] Johnston Janice, Schooling C Mary, Leung Gabriel. A randomised-controlled trial of two educational modes for undergraduate evidence-based medicine learning in Asia. BMC Medical Education, 2009, 9(1).

[6] Leah Naomi Dobrinski. Views of environmental educators on teaching environmental education. Queen's University (Canada), 2010.

[7] Muhammad Imran Omar, Ambreen Shakil. How To Spice Up The Curriculum?. Archives of Pharmacy Practice, 2010, 1(2).

[8] Mostafa Ranai, Parvin Rezai. The Logical Relationship Between the Curriculum and Teaching Models. Procedia - Social and Behavioral Sciences, 2012, Vol.46 , pp.4571-4574.

[9] Nii Antiaye Addy. Comparing teachers' non-teaching roles in curriculum reforms from an organization studies perspective: Cases from Botswana and South Africa. PROSPECTS, 2012, 42(4).

[10] Maria Helena Esteves. Curriculum changes and teacher training: the pedagogy of geography teaching in Portuguese schools. Educate, 2006, 6(2). 